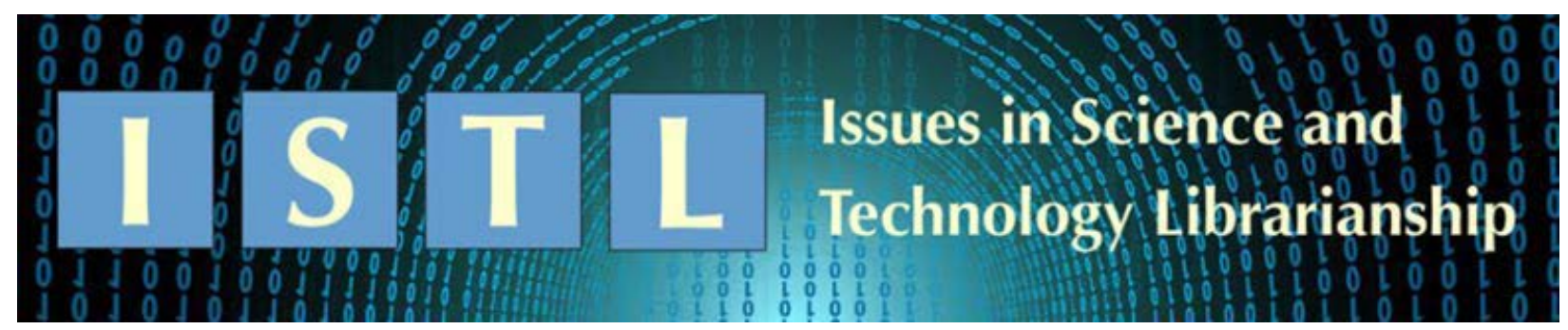

\title{
Gold Route Open Access Journals in Engineering and Technology: Analysis of Research Impact and Implications for Scholarly Communication
}

\author{
Ifeanyi J. Ezema, Ph.D \\ Research Fellow \\ Department of Information Science \\ University of South Africa \\ Nnamdi Azikiwe Library \\ University of Nigeria Nsukka \\ ifeanyi.ezema@unn.edu.ng
}

\begin{abstract}
This study examines the research impact of gold open access (OA) journals in engineering and technology. A total of 37 gold route journals that request article processing charges (APC) and 66 other OA journals without APC (i.e., platinum OA) in the field were found in the Directory of Open Access Journals and used for the study. The publishers, APC charges, and the year each journal was added to DOAJ were identified and included in this study. An informetric approach was used to extract research impact indicators (citations, paper productivity, cite/paper, cite/journal, and h-index) of journals. Findings revealed that the publishers of the APC journals were dominated by commercial publishing companies, producing over $60 \%$ of the journals. Article processing charges ranged from $\$ 7.60$ to $\$ 3,471.50$, with an average of $\$ 727.00$. Gold route open access (APC) journals performed better than open access non-APC OA journals, since they produced $51.2 \%$ of the papers, $71.8 \%$ of the total citations, and $65.1 \%$ of the total hindex. There was a weak positive correlation between the APC amount of the gold route journals and their research impact.
\end{abstract}

\section{Introduction}

The past one and a half decades has witnessed a revolution in scholarly communication with the emergence of open access publishing. Librarians had earlier drawn the attention of the global scientific community to dwindling library budgets and the skyrocketing cost of research literature, leading to what was generally regarded as the serials crisis (Guédon 2004; Beall 2013). Journal publishers appeared to be more interested in the economics of scholarly publishing with regard to high profit margin than providing wider access to research literature. With internet powered publishing opportunities, there was an increasing interest in resolving the challenges of 
the serials crisis. This led to the meeting of the Open Society Institute in 2001, which gave birth to the Budapest Open Access Initiative (BOAI) (see

http://www.budapestopenaccessinitiative.org/read). This was described as the "first internationally focused formal statement to articulate a comment to open access” (Peekkhaus \& Proferes 2015). BOAI provided different open access models, namely, gold route, which often requires payment of article processing charges, and green route, which involves self-archiving in research or institutional/research repositories (Sanchez-Tarrago \& Fernandez-Molina 2009; Peekkhaus \& Proferes 2015). The global estimate of open access journals is about 28,000 in all fields, publishing about 2.5 million articles annually with about $20 \%$ of the journals using the gold route model (ㅂarnad 2015).

Open access publication models, namely, gold, green, and hybrid (publication of gold open access and subscribed articles within the same journal), provide different publication options for scholars (Antelman 2004; Craig et al. 2007; Turk 2008; Tenopir et al. 2017). While the gold and hybrid routes allow the authors to pay article processing charges (APC) as a way of bearing the cost of access to the general public, the green route allows the authors to self-archive their publications in research or institutional repositories or use social media outlets, such as researchgate.net and academic.edu, to share content to the wider scientific community. But, Tenopir et al. (2017) raised concern about the cost of maintaining the institutional repositories and other related challenges in green route open access publishing. There is also a set of established society journals with stable subscription funds, which provide free access to their publications directly or after a period of six months to one year (Laakso et al. 2011). Many other toll-access journals, including top journals in different fields, allow self-archiving of their publications using the green OA. Naturally, open access is believed to enhance wider access and reading of research papers (Laakso et al. 2016) and by extension increase citations and impact of the papers. Harnad et al. (2004) have described citation impact as the "degree to which its findings (research publications) are read, used, applied, built upon, and cited by users to further research and applications.” That is why many publishers are increasingly adopting OA. Similarly, many journals that were originally subscription based have begun to adopt hybrid publication model as a result of pressure from stakeholders, monetary subsidies, and other related issues (Laakso et al. 2016). About 2,400 subscription based journals moved to OA in 2011, and this represents over one third of the journals found in the Directory of Open Access Journals (DOAJ) (Laakso \& Bjork 2012). Recent developments indicate that many publishers are increasingly flipping their journals by adding OA options to their publications. For instance Laakso et al. (2016) posited that Hindawi flipped all its journals to open access to avoid competition arising from major publishers.

Often APC is paid by funding bodies who have commissioned the research. Otherwise, authors must pay, if they desire free access and wider visibility of their papers. Usually, the possible considerations for authors' choice of gold route open access include but are not limited to cost to the authors, mandate from the employer or funding body, visibility of the article, and the open access policy of the journal (Bjork 2012). The campaign for open access publishing resulted in many existing journals transitioning to gold route OA (Guédon 2004; Laakso et al. 2016), while others opted for hybrid publication outlets, so as to join the new publication platform that BioMedical Central and Public Library of Science (PLoS) pioneered in 2002. Other journals adopted hybrid publication as a form of gradual transition to the mainline gold-route publishing. 
Studies indicate that over the years the number of hybrid open access journals have increased tremendously (Laakso et al. 2011; Shamash 2016), but it has not translated to a significant number of articles published using the gold route platform (Bird 2010; Bjork 2012). Many have, however, accused the gold-route model as being costly, risky, and inefficient, and, therefore, authors must be cautious of publishing through the gold route (Guédon 2004; Bjork 2012; Beall 2013). Although there have been author page charges that helped fund some society journals' publishing over the years, the major concern with APC is its extremely high cost, which many authors find difficult to pay. According to Bjork (2012), the cost of publishing in some of the journals is as much as $\$ 3,000$, and, therefore, only 1 to $2 \%$ of eligible authors can publish articles using this model. This is a source of concern to authors and research funders, as observation from DOAJ shows that many journals hosted in it request article processing charges.

DOAJ (see https://doaj.org/) was launched in 2002 during the First Nordic Conference on Scholarly Communication (Stenson 2011). Since then, DOAJ hosts a number of open access journals from many countries all over the world under the Creative Commons Attribution license (https://creativecommons.org/licenses/by/2.0/), which permits sharing and adapting content for any purpose, even for commercial uses. The last two decades witnessed an increase in publication of open-access journals funded through article processing charges from authors (Fox \& Hanlon 2015) or through funding from agencies and organizations. This has provided free access to research literature and created wider visibility and readership to authors. As of November 10, 2016, when the data for this research was extracted, there were 9,250 journals and 6,450 searchable journals at article levels with 2,333,303 articles from 128 countries in DOAJ. This showed a remarkable increase from 1,825 journals as reported by Solomon and Bjork (2012a). There are 1,767 journals with APC and 3,685 non-APC journals in DOAJ at the time of this study.

The focus of this study is on engineering and technology, and these fields were considered because of the critical role they play in the overall technological development of any nation and even globally. History has also shown the application of science and technology drives sustainable development (Mashi et al. 2014). Hence, countries that have attained a high level of technological development have better human development indicators (UNDP 2018). In recognition of this the G7 Academies Statement (2017) urged the G7 countries to invest more in science and technology because of their capacity to drive sustainable socio-economic development. They are also fields that require current information, such as that found in the journal literature.

Consequently, it is very important to investigate issues related to scholarly communication in the discipline. Since there are several open access publication routes for researchers in the discipline, it should be of interest to interrogate economics of these routes in relation to their scholarly impact.

The concern is how the demand of APC affects researchers who may not have enough funds to pay as a result of low income and very slim opportunities to attract research grants. Harnad (2015) has also expressed the challenges of institutions that pay for APC and at the same time subscribe to toll access journals to meet the needs of the users. Authors such as Wray (2016) and Beall (2013) are, therefore, concerned about the value they get from APC journals compared to 
non-APC open access journals. What other additional advantages accrue to the author to justify such payment?

\section{Purpose of the study}

The purpose of this study is to examine the research impact of gold route APC OA journals in relation to the article processing charges the journals request. Specifically, the study intends to

1. Identify APC engineering and technology journals and their charges

2. Identify publishers of APC journals in engineering and technology

3. Determine and compare the productivity and impact of APC and non-APC journals

4. Determine the relationship between APCs and research impact

5. Examine the trends in the growth of APC journals in Engineering and Technology

\section{Literature Review}

Though adoption of open access publishing has increasingly grown over time, earlier concern has been that OA often focused on articles rather than journals, since the papers are published independent of the journals (Guédon 2004). With self-archiving, the article becomes preeminent, while the journal only serves as a brand that provides information on papers that were peer-reviewed and those that were not. Though, there are variations in the two publication routes, Guédon (2004) remarked that they are complementary to each other rather than being in competition. However, the gold route model publishing presents to the publishers an attractive offer capable of increasing profit margin in academic publishing. Guédon (2008) has alluded to the economics of scholarly publishing when he remarked that some of the established publishers have created a form of elite club which dominates scholarly publishing, making it extremely difficult to admit neophytes. It is even becoming more monopolistic when university ranking bodies drive their ranking indicators from Web of Science and Scopus, which are dominated by journal portfolios from established publishers, such as Emerald, Elsevier, Springer, and Taylor \& Francis, among others (Guédon 2008; Solomon \& Bjork 2012b). With this development, it is imperative to understand that very few scientists can or desire to publish in some of these journals using the gold-route option. This is evident from the study of Tenopir et al. (2017), which reported that respondents surveyed were willing to pay APCs not exceeding $\$ 100$, which is far lower than what many of the gold route journals charge. Shamash (2016) reported that, for the past two years, the average APC has increased by 6\%, which is far above the cost of inflation in many countries. The concern here is the fear of established publishers hijacking the gold route publication model for the purpose of maximizing profit.

Consequently, some studies have attempted to investigate adoption of APC by journals and their publishers. A study by Walters and Linvill (2011) examined 663 journals hosted in DOAJ in six fields of biology, computer science, economics, history, medicine, and psychology, and found that $29 \%$ of journals that charged APC produced $50 \%$ of the articles produced. The average APC was $\$ 1,109$ with a median of \$1,300. McVeigh and Pringle (2005) reported that $27 \%$ of the 174 medical journals in the Web of Science were open access and another 14\% were hybrid journals. A comprehensive Study of Open Access Publishing (SOAP) conducted by Dallmeier et al. (2010) collected data on 2,823 active English-language journals hosted in DOAJ and identified 
14 large publishers with $80 \%$ of journals requesting APC. Another study by Solomon and Bjork (2012b) found that the major sources of funding for APC publications above $\$ 1,000$ were through research grants and institutional affiliations. There are also variations in the response of authors across disciplines and geographical areas, as authors from high-income countries with research funding respond more positively to APC than those from low-income countries.

Given the high publication charges of some journals, authors are often careful in their choice of journals when submitting their papers. Swan and Brown (1999 and 2004) found that factors that authors consider while choosing journals for their paper submission were readership (wider reach to researchers within and outside the discipline) and quality of journals, while Coupé (2004) remarked that authors equally consider the possibility of rejection of the papers. A related study by Schroter et al. (2006) identified research impact, reputation, readership, speed of publication, and quality of peer review as major considerations of authors in the choice of journals in submitting their papers. All these fall under the framework of Bjork and Holmström's (2006) 29 factors aggregated into four groups: infrastructure, readership, prestige, and performance.

Because of the article processing charges, there appears to be slow growth in the gold route OA publishing as reported in the study of Dallmeier et al. (2010), which revealed that Springer's gold route option had grown from $0 \%$ in 2004 to 1\% in 2009; while the study of Bjork (2012) revealed that OA articles from journal portfolios from American Physical Society from 2007 to 2010 constituted only $0.3 \%$, and Elsevier recorded less than $1 \%$ of sponsored articles in their gold route model, and this accounted for less than $0.1 \%$ of its total revenue in 2012. Bjork therefore concludes that the hybrid experiment has failed to add a significant number of OA articles through the gold route.

It is, therefore, contentious whether gold route OA has any relative value in scholarly communication. Wray (2016) has argued that there was no benefit in gold route OA considering the huge charges from publishers. Although several studies found citation advantage to openaccess publishing (Antelman 2004; Metcalfe 2006; Craig et al. 2007; Turk 2008; Wagner 2010; Davis 2011), only a few of them have shown evidence of citation advantage through gold route OA publications (Shin 2003; Eysenbach 2006). According to Wray (2016), the supposed citation benefit reported by Sotudeh et al. (2015) was an artifact of the method used in measuring impact, as such citation advantage was absent in humanities and social sciences. Apart from this, Beall (2013) contended that the entrance of predatory journal publishers cast serious doubt on the success of gold route open access model. Other recent studies alluded to the danger of predatory open access journals in remarking that the major interest of such journals was mainly article processing charges rather than the scholarly peer review mechanism of reputable journals (Shen \& Bjork 2015; Webster \& Butler 2014; Christopher \& Young 2015).

Others studies have equally questioned the quality control mechanism in OA publishing. Harnad (1998) underscored the need for peer review process in science and insisted that works must undergo peer review so that other researchers would rely on the paper for further research. Beall (2013) argued that the ability to pay APC is now a major determinant in accepting papers rather than the quality of the paper, usually determined through peer review mechanism, resulting in many referring to OA publishing as "pay to say." Beall (2013) remarks that misconduct, such as piracy and plagiarism (including self-plagiarism), have been confirmed by searching plagiarized 
passages on the Internet, and these peer review related issues have begun to cast doubt on whether some research results are procedurally scientific.

Given these problems associated with gold route open access, researchers are worried about the fate of the open access movement in achieving free access to research literature. Harnad (2015) had argued that the best way to optimize a $100 \%$ open access is a self-archiving mandate to populate various institutional and research repositories all over the world. Ezema (2011) had earlier highlighted the need for development of institutional repositories, particularly in developing countries, for wider visibility of research outputs. A related work (Ezema \& Ugwu 2013) also underscored the relevance of creating electronic theses and dissertations to provide wide access to primary research findings of African origin.

\section{Methods}

This study adopted a descriptive informetric approach and extracted data from DOAJ with several indictors related to this study. DOAJ has a built-in search mechanism capable of filtering journals by title, subject, type of OA route, publishers, country of publication, and year added to the database, among other metadata. At the time of this study there were 104 engineering and technology journals listed in DOAJ, out of which 37 request article processing charges, while 67 do not. Hybrid journals were excluded from the journals used for the analysis, because articlelevel deference is beyond the scope of the methodology employed in the study. The details about the journals used for the study and their status in the major international indexing bodies are provided in Appendix 1.

The journal titles were entered into Harzing's Publish or Perish (PoP) software (Harzing 2007) to extract relevant data for measurement of research impact. Google Scholar was used to extract informetric data of the journals, namely the total number of papers, total number of citations, number of citations per paper, number of citations per year, and h-index for a five-year period. The extracted data was manually cleaned to remove duplicate citation data and incorrect citations. One of the non-APC journals (EAI Endorsed Transactions on Wireless Spectrum) was not recognized by the Publish or Perish software, so, it was dropped from the list and only 66 non-APC journals and 37 APC journals were used for this analysis. Data on citation indicators of the journals were exported to Microsoft Excel to determine their research impact. These journals were searched in two other major indexing bodies, namely, Web of Science (WoS) and Scopus, for comparison of their research impact. Unfortunately, the search yielded very low results, as only three of the journals were indexed in WoS and 11 in Scopus.

The article publication charges paid for each of the journals was obtained from the DOAJ web site and converted to US dollars using the exchange rate available online at the time of the study. The correlation of the research impact of the journals was based only on the data from Google Scholar, because of the very low presence of the journals in WoS and Scopus. The SPSS statistical package was used to determine the correlation between APC (in US dollars) and the research impact measured by h-index, citation counts, and number of papers published by the top twenty gold route OA (APC) journals. The same statistical software was used to investigate the correlation of h-index between APC and non-APC titles. 


\section{Results}

Of the 37 APC journals studied, Microsystems \& Nanoengineering has the highest APC of $\$ 3,471.50$ and Journal Keteknikan Pertanian has the lowest (\$7.60), with an average APC of $\$ 727.00$. Appendix 1 provides a list of the APC charges of each journal. It is important to observe that the journal with highest APC is not among the top twenty ranked gold route journals, and the high ranked APC journals have relatively lower charges than other low ranked journals.

Table 1. Publishers of gold route (APC) journals

\begin{tabular}{|l|l|l|}
\hline \multicolumn{1}{|c|}{ Publishers } & Number of Journals & \% \\
\hline Hindawi & 10 & 27.0 \\
\hline Elsevier & 5 & 13.5 \\
\hline Springer & 3 & 8.1 \\
\hline MDPI & 2 & 5.4 \\
\hline Taylor \& Francis & 2 & 5.4 \\
\hline BioMed Central & 1 & 2.7 \\
\hline Other institutional publishers & 14 & 37.9 \\
\hline Total & 37 & 100 \\
\hline
\end{tabular}

Publishers of gold route open access journals are presented in Table 1, showing that commercial publishers (Hindawi, Taylor \& Francis, Elsevier, Springer, and MDPI) account for over $60 \%$ of all the titles (see Appendix 2 for a list of APC journals and their publishers). Fourteen institutional publishers have one journal each.

Table 2. Research impact of gold route (APC) and Non-APC journals $(\mathrm{N}=103)$

\begin{tabular}{|l|l|l|l|l|l|l|l|l|}
\hline $\begin{array}{c}\text { Type of } \\
\text { OA } \\
\text { Journal }\end{array}$ & $\begin{array}{c}\text { Number } \\
\text { of } \\
\text { Journals }\end{array}$ & $\begin{array}{c}\text { Total } \\
\text { Papers }\end{array}$ & Paper/journal & $\begin{array}{c}\text { Total } \\
\text { Citations }\end{array}$ & Cite/Journal & Cite/Paper & $\begin{array}{c}\text { Total } \\
\text { H- } \\
\text { Index }\end{array}$ & $\begin{array}{c}\text { Mean } \\
\text { H- } \\
\text { Index }\end{array}$ \\
\hline $\begin{array}{l}\text { Gold } \\
\text { route } \\
\text { (APC) }\end{array}$ & 37 & 12403 & 335.2 & 51454 & 1390.7 & 4.2 & 351 & 9.5 \\
\hline $\begin{array}{l}\text { Non- } \\
\text { APC } \\
\text { Journals }\end{array}$ & 66 & 11812 & 178.0 & 20199 & 306.1 & 1.7 & 338 & 5.1 \\
\hline Total & 103 & 24215 & & 71653 & & & 689 & \\
\hline
\end{tabular}


A comparison of the research impact of APC and non-APC open access journals is presented in Table 2. Evidently, APC journals have greater research impact despite there being fewer than non-APC journals. Similarly, the APC journals published more articles than non-APC journals. More surprisingly, APC journals received $71.8 \%$ of the total citations. Therefore, in terms of citations, cite per paper, and cite per journal, APC journals are performing better, and the mean h-index is higher, than non-APC journals.

The growth of open access journals in engineering and technology has been very slow, but the growth rate is higher with non-APC than APC OA, as can be seen in Table 3. DOAJ began hosting two journals in 2002. In 2009, it recorded a growth rate of $4.4 \%$ until 2013, when there was a growth rate of $13 \%$ for APC journals, with the highest growth rate of $27 \%$ in 2015 . The non-APC journals, however, have their highest growth rate of 46\% in 2015.

Table 3. Trends in adoption of open access journals as reflected in DOAJ

\begin{tabular}{|l|l|l|l|l|l|l|}
\hline Years & APC & $\begin{array}{c}\text { \% APC } \\
\text { titles }\end{array}$ & $\begin{array}{c}\text { Non- } \\
\text { APC }\end{array}$ & $\begin{array}{c}\text { \% of non-APC } \\
\text { titles }\end{array}$ & $\begin{array}{c}\text { Total APC and non- } \\
\text { APC titles }\end{array}$ & $\begin{array}{c}\text { \% of all OA } \\
\text { titles }\end{array}$ \\
\hline 2016 & 9 & 24.3 & 20 & 29.9 & 29 & 25.4 \\
\hline 2015 & 10 & 27.0 & 31 & 46.3 & 41 & 44.7 \\
\hline 2014 & 2 & 5.4 & 3 & 4.5 & 5 & 4.4 \\
\hline 2013 & 5 & 13.5 & 2 & 3.0 & 7 & 6.1 \\
\hline 2012 & 1 & 2.7 & 4 & 6.0 & 5 & 4.4 \\
\hline 2011 & 1 & 2.7 & 2 & 3.0 & 3 & 2.6 \\
\hline 2010 & 0 & 0 & 1 & 1.5 & 1 & 0.9 \\
\hline 2009 & 3 & 8.1 & 2 & 3.0 & 5 & 4.4 \\
\hline 2008 & 0 & 0 & 0 & 0 & 0 & 0 \\
\hline 2007 & 2 & 5.4 & 0 & 0 & 2 & 1.8 \\
\hline 2006 & 1 & 2.7 & 1 & 1.5 & 2 & 1.8 \\
\hline 2005 & 0 & 0 & 1 & 0 & 1 & 0.9 \\
\hline 2004 & 1 & 2.7 & 0 & 0 & 1 & 0.9 \\
\hline 2003 & 0 & 0 & 0 & 0 & 0 & 0 \\
\hline 2002 & 2 & 5.4 & 0 & 0 & 2 & 1.8 \\
\hline Total & 37 & & 67 & & 104 & \\
\hline
\end{tabular}

The result of the correlation of the amount paid for article processing charges (APC), valued in US dollars, and research impact of the journals measured by number of papers published, citation counts, and h-index is shown in the correlation matrix (see Table 4). Interpretation of correlation 
coefficient ( $r$ ) was determined using Rumsey (2010), which provides that $r$ value close to 0.30 is weak, 0.50 is moderate, 0.70 is strong, and 1 is perfect correlation. The correlation between APC and number of papers published is weak and not significant $(r=0.275, p>0.05)$, but APC has a significant positive, but weak, correlation with citations $(r=0.366, p<0.05)$. In the same way, APC has a significant positive but weak correlation with the h-index of the journals $(r=0.392, p$ $<0.05$.) The implication of this finding is that the amount of the article processing charge has very little relationship with the research impact of the journals.

Table 4. Spearman's rho correlation matrix of APC and journal research impact

\begin{tabular}{|c|l|l|l|l|l|}
\hline & & APC (in US\$) & Papers & Cites & H-index \\
\hline APC & Correlation Coefficient & 1.000 & .275 & $.366^{*}$ & $.392^{*}$ \\
\hline & Significance (2-tailed) & - & .099 & .026 & .016 \\
\hline Papers & Correlation Coefficient & .275 & 1.000 & $.800^{* *}$ & $.753^{* *}$ \\
\hline & Significance (2-tailed) & .099 & - & .000 & .000 \\
\hline Cites & Correlation Coefficient & $.366^{*}$ & $.800^{* *}$ & 1.000 & $.951^{* *}$ \\
\hline & Significance (2-tailed) & .026 & .000 & - & .000 \\
\hline H-index & Correlation Coefficient & $.392^{*}$ & $.753^{* *}$ & $.951^{* *}$ & 1.000 \\
\hline & Significance (2-tailed) & .016 & .000 & .000 & - \\
\hline $\mathbf{N}$ & & 37 & 37 & 37 & 37 \\
\hline $\begin{array}{l}{ }^{*} \text { Correlation is significant at the 0.05 level (2-tailed). } \\
\text { "*Correlation is significant at the 0.01 level (2-tailed). }\end{array}$ & & & \\
\hline
\end{tabular}

\section{Discussion}

Findings of this study provide greater understanding of the scholarly implications of the gold route open access publication model. With more non-APC open access model journals in engineering and technology, one would have expected minimal article processing charges from gold OA journals, but many of the journals collect more than \$1,000, with an average APC of $\$ 727$. These charges are extremely high and do not reflect the income of many scholars, particularly in the developing countries, where the average monthly salary is usually less than $\$ 1,000$. This is why many studies have leveled criticisms against high APC for many gold route OA journals (see Cozzarelli et al. 2004; Dallmeier et al. 2010). These charges may also account for the reluctance of institutions and authors to pay, as has been reported by Harnad (2015). With this development, the philosophy behind the open access movement is jeopardized, because a large majority of authors are excluded from the opportunity of publishing in journals of their choice once they cannot afford APC.

It is not surprising that commercial publishers dominate gold route open access publishing, given the economics of academic publishing. Previous studies (Walters \& Linvill 2011; Solomon \& Bjork 2012a) have often associated gold route (APC) open access publishing with commercial 
publishers who are interested in increasing profit margin. Already, a lot of the journals are hybrid journals, where authors have option of paying APC for open access or publish without open access. This development relates to the concern of Guédon (2008), when he accused commercial publishers of creating an elite club that takes advantage of authors' interest in publishing in higher impact open access journals, where their papers are freely shared among colleagues across the globe for wider readership and greater research impact. As can be observed, almost half of the journals in this study are published by Hindawi, Elsevier, and Springer. (Guédon 2008; Bjork 2012; Solomon \& Bjork 2012b) have earlier identified these established companies as pioneers of APC gold route open access publishing, and they have continued to popularize it ever since.

In the field of engineering and technology, APC journals have greater research impact than their non-APC counterparts in all the research indicators, such as number of papers published, citations, h-index, and citations per paper. Findings revealed that even though the gold route APC had fewer journals, they published over $50 \%$ of all papers and generated over $70 \%$ of the total citations. This is in line with earlier studies (Shin 2003; Eysenbach 2006). Though, open access publishing implies that all the journals are freely available on the Internet, providing equal opportunity for visibility and access, many readers would be more interested in accessing journals from established publishing companies and indexed in major international databases such as Web of Science and Scopus. A close observation of the performance of the journals revealed that the top twenty journals are published by established commercial publishing companies, where many authors usually submit their papers. A content analysis of papers published in these journals may provide a better insight in the quality of papers published in both OA types.

This study also shows that engineering and technology journals have a slow growth rate in open access publishing with only two journals in 2002 and increasing slowly until 2015 and 2016. This is contrary to the reported rapid growth of OA publishing in a study by Laakso et al. (2011), but supports the findings of Dallmeier et al. (2010), which attributed the slow growth to high APC; and it could also be that the growth of APC journals varies according to disciplines.

Although findings reveal a correlation between article processing charges and research impact of the journals, the effect size is relatively small. This is contrary to the belief of many authors who pay APC to increase their research impact. This assumption has been reflected in several studies that identify research impact and reputation of the journals as major considerations in selection of publication outlets of their papers (see Bjork \& Holmström 2006; Schroter et al. 2006). This finding increases the contentious nature of research impact of APC journals, which Wray (2016) has questioned. Although Shin (2003) and Eysenbach (2006) found citation advantage of APC over non-APC journals, the studies failed to show whether this advantage correlates with the article processing charges of the journals and how significant is the correlation. The concern here is whether the introduction of APC by publishers has any scholarly benefits. Beall's (2013) argument that the major concern of gold route publishing is the ability to pay rather than the scholarly quality of the papers should be taken very seriously. Researchers should also worry about the level of peer review mechanism of gold route OA journals, which Harnad (1998) and Beall (2013) have questioned. 


\section{Implications for Scholarly Communication and Open Access Movement}

The enthusiasm to embrace the open access movement by the global scientific community as a solution for the serials crisis in libraries has been underscored by a number of scholars (Dallmeier et al. 2010; Ezema 2011, Ezema \& Onyancha 2016; Walters \& Linvill 2011). However, the introduction of APC by some publishing companies excludes a large majority of authors from contributing to the scholarly communication process. The major interest of authors is to widely disseminate their research findings to colleagues using reputable and widely circulated journals. Though it is yet to be established whether interest in APC is mainly for higher profit margin, publishers could be swayed by the high charges to the detriment of quality assurance. Such could also increase the possibility of ignoring some quality research papers.

Many are interested in the open access movement, because it tries to bridge the knowledge gap and digital divide between the advanced countries and the developing countries (Peekkhaus \& Proferes 2015; Fox \& Hanlon 2015). Studies have shown that research and knowledge production in developing countries, particularly in Africa, is comparatively low (Ezema 2010; Gaillard 2010; Nwagwu 2013), but the gold route OA publishers are increasingly reducing research productivity of low-income countries through high APC. Though some publishers may grant a waiver of the charge, when authors apply, these waivers may not be forthcoming. It has been shown that gold route OA is usually funded by grants from organizations and institutions (Solomon \& Bjork 2012b), but research funding in low-income countries is rare or completely absent. Considering the income of such researchers, few authors can afford the high charges of many gold route journals. The obvious implication is that quality research papers from these disadvantaged authors may never be published in gold route OA, where they are likely to receive higher research impact, and this perpetuates low knowledge production in low-income countries and robs the global research community of quality papers that would have contributed to the advancement of scientific knowledge.

For years, libraries have borne the burden of providing research literature to their teeming users, and that is why librarians were concerned about the serials crisis in late 1990's and early 2000's. The expectation is that with the open access initiative, this financial burden on libraries will be reduced, but the introduction of APC journals appears to have compounded the problem. The socalled hybrid journals accept APC from authors and institutions, and, this notwithstanding, libraries still pay subscription fees for users to access articles in the same journals. This double payment denies many institutions and libraries funds that could have been channeled to other areas to satisfy the demands of the users for their research.

The philosophy behind the Budapest Open Access Initiative is to provide free availability of information, which by extension implies the publication of such information for wider visibility and access. The concern here is that APC appears to be a constraint to the free flow of information and erodes the philosophy of open access. Scholars have already observed that it is an attempt to create an opportunity for established publishers to monopolize academic publishing (see Beall 2013; Bjork 2012; Harnad 1998; Harnad 2015) racking up millions of dollars at the expense of authors and funding agencies. This negates all that the open access movement represents, and there is a need to create awareness on the dangers of APC on scholarly communication and the open access movement. This is why authors, libraries, institutions, and professional associations should give serious consideration to self-archiving articles in 
repositories, as has been recommended by a number of studies (Ezema 2011; Harnad 1998;

Harnad 2015). This green route option provides a good alternative for authors; and since some of the toll access journals allow for archiving of articles, Harnad (2015) posits that with selfarchiving mandates from institutions and organizations, there would be $100 \%$ open access to research literature, if authors would ignore the antics of gold route open access publishers.

\section{Conclusion}

Open access publishing is an attempt to promote free access to information to the global scientific community. This paper has attempted to contribute to the debate on open access publishing with a focus on the research impact of gold route open access journals in relation to article processing charges, which the journals request from author and funding bodies. In engineering and technology, a greater proportion of OA journals that request APC are published by established publishing companies who can charge more than $\$ 2,000$. Though APC journals have greater research impact as seen in the findings, the research impacts of the journals do not seem to justify the high APC charges from the publishers, since there are only weak correlations between the charges and the research impact metrics, such as citations and h-index, and no significant correlation in terms of number of papers published. The increasing number of APC journals over the years should, therefore, be a source of concern, given the high charges as it appears to be antithetical with the philosophy of open access movement and scholarly communication. This therefore, justifies the need for increased awareness of the danger of gold route open access publishing for the global scientific community. If free flow of information in line with the open access movement must be guaranteed, the gold route open access model should be discouraged and researchers should be encouraged to freely disseminate their research outputs through self-archiving in repositories and other available channels.

\section{References}

Antelman, K. 2004. Do open-access articles have a greater research impact? College \& Research Libraries 65(5):372-382. DOI: 10.5860/crl.65.5.372.

Beall, J. 2013. Predatory publishing is just one of the consequences of gold open access. Learned Publishing 26:79-84. DOI: 10.1087/20130203

Bird, C. 2010. Continued adventures in open access: 2009 perspective. Learned Publishing 23(2):107-116. DOI: $\underline{10.1087 / 20100205}$

Bjork, B.-C. 2012. The hybrid model for open access publication of scholarly article: A failed experiment? Journal of the American Society for Information Science and Technology 63(8):1496-1504. DOI: 101002/asi.22709.

Björk, B.-C., \& Holmström, J. 2006. Benchmarking scientific journals from the submitting author's viewpoint. Learned Publishing 19(2):147-155. DOI: $10.1087 / 095315106776387002$ 
Christopher, M.M. \& Young K.M. 2015. Awareness of "predatory" open-access journals among prospective veterinary and medical authors attending scientific writing workshops. Frontiers in Veterinary Science 2:1-11. DOI: 10.3389/fvets.2015.00022.

Coupé, T. 2004. What do we know about ourselves? On the economics of economics. KYKLOS 57(2):197-216. DOI: 10.1111/j.0023-5962.2004.00250.x

Cozzarelli, N., Fulton, K. \& Sullenberger, D. 2004. Results of a PNAS author survey on an open access option for publication. Proceedings of the National Academy of the Sciences 101(5):1111. DOI: 10.1073/pnas.0307315101.

Craig, I.D., Plume, A.M., McVeigh, M.E., Pringle, J. \& Amin, M. 2007. Do open access journals have greater citation impact? A critical review of the literature. Journal of Informetrics 1:239-248. DOI: $\underline{\text { 10.1016/j.joi.2007.04.001 }}$

Dallmeier-Thiessen, S., Goerner, B., Darby, R., Hyppoelae, J., Igo-Kemenes, P., Kahn, D., Lambert, S., Lengenfelder, A., Leonard, C., Mele, S., et al. 2010. Open access publishingmodels and attributes, SOAP project report, Max Planck Society Digital Library. Retrieved from: http://edoc.mpg.de/478647.

Davis, P.M. 2011. Open access, readership, citations: A randomized control trial of scientific journal publishing. FASEB Journal 25:2129-2134. DOI: 10.1096/fj.11-183988.

Eysenbach, G. 2006. Citation advantage of open access articles. PLoS Biology 4(5):e157. DOI: 10.1371/journal.pbio.0040157.

Ezema, I.J. 2010. Trends in electronic journal publishing in Africa: An analysis of African Journal Online (AJOL). Webology 7(1). Available at https://webology.org/datacms/articles/20200515040154pma74.pdf.

Ezema, I.J. 2011. Building open access institutional repositories for global visibility of Nigerian scholarly publication. Library Review 60(6):473-485. DOI: 10.1108/00242531111147198.

Ezema, I.J. \& Onyancha, O.B. 2016. Status of Africa in the global open access directories: Implications for global visibility of African scholarly research. Fourth CODESRIA Conference On Electronic Publishing: Open Access Movement and the Future of African Knowledge Economy, Dakar, Senegal March 30 - April 1, 2016. Available at https://www.codesria.org/IMG/pdf/ezema_onyancha.pdf.

Ezema, I.J. \& Ugwu, C.I. 2013. Electronic theses and dissertations in Nigeria university libraries: Status, challenges and strategies. Electronic Library 31(4):493-507. DOI: 10.1108/EL08-2011-0118.

Fox, M. \& Hanlon, S.M. 2015. Barriers to open access uptake for researchers in Africa. Online Information Review 39(5):698-716. DOI: 10.1108/OIR-05-2015-0147. 
G7 Academies 2017. New economic growth: The role of science, technology, innovation and infrastructure. Retrieved from http://www.scj.go.jp/ja/info/kohyo/pdf/kohyo-23-gs2017-5.pdf.

Gaillard, J. 2010. The characteristics of R\&D in developing countries. Science, Technology and Society 15:77-111. DOI: 10.1177/097172180901500104.

Guédon, J.-C. 2004. The "green" and "gold" roads to open access: The case of mixing and matching. Serials Review 30(4):315-328. DOI: 10.1080/00987913.2004.10764931.

Guédon, J.-C. 2008. Mixing and matching the green and gold roads to open access - Take 2. Serials Review 34(1):41-51. DOI: 10.1080/00987913.2008.10765151.

Harnad, S. 1998.The invisible hand of peer review. Nature. DOI: 10.1038/nature28029.

Harnad, S. 2015. Optimizing open access policy. Serials Librarian 69(2):133-141. DOI: 10.1080/0361526X.2015.1076368.

Harnad S., Brody T., Valliáres F., Carr L., Hitchcock S., Gingras Y., Oppenheim C., Stamerjohanns H. \& Hilf E.R. 2004. The access/impact problem and the green and gold roads to open access. Serials Review 30(4):310-314. DOI: 10.1080/00987913.2004.10764930.

Harzing, A. W. 2007. Publish or perish. Available at https://harzing.com/resources/publish-orperish.

Laakso, M., \& Bjork, B.-C. 2012. Anatomy of open access publishing: A study of longitudinal development and internal structure. BMC Medicine 10:124. DOI: 10.1186/1741-7015-10-124.

Laakso, M., Solomon, D. \& Bjork, B.-C. 2016. How subscription-based scholarly journals can convert to open access: A review of approach. Learned Publishing 29:259-269. DOI: 10.1002/leap.1056.

Laakso, M., Welling, P., Bukvova, H., Nyman, L., Björk, B.-C., \& Hedlund, T. 2011. The development of open access journal publishing from 1993 to 2009. PLoS ONE 6(6):e20961. DOI: 10.1371/journal.pone.0020961.

Mashi, S.A., Inkani, I.I. \& Yaro, A. 2014. An appraisal of the role of science and technology in promoting national development efforts in Nigeria. International Journal of Engineering and Science 3(2):56-67. Available at http://www.theijes.com/papers/v3-i2/Version3/G032030056067.pdf.

McVeigh, M.E. \& Pringle, J.K. 2005. Open access to the medical literature: How much content is available in published journals? Serials 18(1):45-50. DOI: 10.1629/1845.

Metcalfe, T.S. 2006. The citation impact of digital preprint archives for solar physics papers. Solar Physics 239:549-553. DOI: 10.1007/s11207-006-0262-7. 
Nwagwu, W.E. (2013). Open access initiatives in Africa - Structures, incentives and disincentives. The Journal of Academic Librarianship 19(1):3-10. DOI: 10.1016/j.acalib.2012.11.024.

Peekkhaus, W. \& Proferes, N. 2015. How library and information science faculty perceive and engage with open access. Journal of Information Science 41(5):640-661. DOI: 10.1177/0165551515587855.

Rumsey, D.J. 2010. Statistical Essentials For Dummies. New York, John Wiley.

Sánchez-Tarragó N. \& Fernández-Molina J.C. 2009. The open access movement and Cuban health research work: An author survey. Health Information and Libraries Journal 27:66-74. DOI: $10.1111 / \mathrm{j} .1471-1842.2009 .00852 . x$.

Schroter, S., Tite, L., Hutchings, A. \& Black, N. 2006. Differences in review quality and recommendations for publication between peer reviewers suggested by authors or by editors. Journal of the American Medical Association 295(3):314-317. DOI: 10.1001/jama.295.3.314.

Shamash, K. 2016. Article Processing Charges (APCs) and Subscriptions: Monitoring Open Access Costs. Bristol: JISC.

Shen, C. \& Björk, B.-C. 2015. Predatory open access: A longitudinal study of article volumes and market characteristics. BMC Medicine 13(230):1-15. DOI: 10.1186/s12916-015-0469-2.

Shin, E.-J. 2003. Do impact factors change with change of medium? A comparison of impact factor when publication is by paper and through parallel publishing. Journal of Information Science 29(6):527-533. DOI: 10.1177/0165551503296009.

Solomon, D.J. \& Bjork, B.-C. 2012a. A study of open access journals using article processing charges. Journal of the American Society for Information Science and Technology 63(8):14851495. DOI: $\underline{10.1002 / a s i .22673 .}$

Solomon, D.J. \& Björk, B.-C. 2012b. Publication fees in open access publishing: Sources of funding and factors influencing choice of journal. Journal of the American Society for Information Science and Technology 63(1):98-107. DOI: 10.1002/asi.21660.

Sotudeh, H., Ghasempour, Z., \& Yaghtin, M. 2015. The citation advantage of author-pays model: The case of Springer and Elsevier OA journals. Scientometrics 104:581-608. DOI: 10.1007/s11192-015-1607-5.

Stenson, L. 2011. The development of Directory of Open Access Journals. Sciecominfo: NordicBaltic Forum for Scientific Communication 7(1):1-4. Available from http://journals.lub.lu.se/index.php/sciecominfo/article/view/4912.

Swan, A., \& Brown, S. 1999. 'WHAT AUTHORS WANT:' The ALPSP research study on the motivations and concerns of contributors to learned journals. Learned Publishing. 12(3):170172. DOI: $10.1087 / 09531519950145742$. 
Swan, A., \& Brown, S. 2004. Authors and open access publishing. Learned Publishing 17:219224. DOI: $10.1087 / 095315104323159649$.

Tenopir, C., Dalton, E., Christian, L., Jones, M.K., McCabe, M., Smith,M. \& Fish, A. 2017. Imagining a gold open access future: Attitudes, behaviors, and funding scenarios among authors of academic scholarship. College \& Research Libraries 78(6):824-843. DOI:

$\underline{10.5860 / \mathrm{crl} .78 .6 .824 .}$

Turk, N. 2008. Citation impact of open access journals. New Library World 109(1/2):65-74. DOI: $\underline{10.1108 / 03074800810846010 .}$.

United Nations Development Programme. 2018. Human Development Indices and Indicators 2018 Statistical Update. New York: UNDP. Available from http://hdr.undp.org/sites/default/files/2018_human_development_statistical_update.pdf.

Wagner, A.B. 2010. Open access citation advantage: An annotated bibliography. Issues in Science and Technology Librarianship 60. DOI: 10.5062/F4Q81B0W.

Walters, W.H. \& Linvill, A.C. 2011. Characteristics of open access journals in six subject areas. College \& Research Libraries 72(4):372-392. DOI: 10.5860/crl-132.

Webster, J. \& Butler, B. 2014. The good, the muddle and the predatory: Open access journals in marine \& aquatic sciences. Presented at the 40th IAMSLIC Conference, Noumea, New Caledonia September 2014.

World Bank. 2017. World Development Indicators 2017. Washington, DC: International Bank for Reconstruction and Development. Available from http://hdl.handle.net/10986/26447.

Wray, K.B. 2016. No evidence for citation benefit for Author-Pay Open Access Publications in social sciences and humanities. Scientometrics 106:1031-1035. DOI: 10.1007/s11192-016-1833$\underline{5}$. 


\section{Appendix 1}

Open Access Journals in Engineering and Technology with APC Charges and Research Impact

\begin{tabular}{|c|c|c|c|c|c|c|c|c|c|}
\hline & Journals & ISSN & \begin{tabular}{|c} 
Date \\
added \\
to \\
DOAJ \\
\end{tabular} & APC & Papers & Cites & $\begin{array}{l}\text { Cites/ } \\
\text { paper }\end{array}$ & $\begin{array}{l}\text { Cites/ } \\
\text { year }\end{array}$ & h-index \\
\hline 1 & $\begin{array}{l}\text { Mathematical Problems in } \\
\text { Engineering }\end{array}$ & $\begin{array}{l}1024- \\
123 X\end{array}$ & 2002 & $\$ 2,000$ & 4,057 & 14,304 & 3.5 & $2,860.8$ & 49 \\
\hline 2 & Materials & $\begin{array}{l}1996- \\
1944\end{array}$ & 2009 & $\begin{array}{l}1400 \mathrm{CHF} \\
(\$ 1,428)\end{array}$ & 2715 & 25,113 & 9.2 & $5,022.6$ & 47 \\
\hline 3 & Beilstein Journal of Nanotechnology & $\begin{array}{l}2190- \\
4286\end{array}$ & 2012 & Non-APC & 827 & 5,965 & 7.21 & 1,193 & 36 \\
\hline 4 & Landtechnik & $\begin{array}{l}0023- \\
8082\end{array}$ & 2015 & Non-APC & 1,403 & 2,131 & 1.5 & 426.2 & 20 \\
\hline 5 & $\begin{array}{l}\text { Advances in Natural Sciences: } \\
\text { Nanoscience and Nanotechnology }\end{array}$ & $\begin{array}{l}2043- \\
6262\end{array}$ & 2011 & Non-APC & 420 & 2,222 & 5.3 & 444.4 & 20 \\
\hline 6 & Applied Sciences & $\begin{array}{l}2076- \\
3417\end{array}$ & 2012 & $\begin{array}{l}\text { 500CHF } \\
(\$ 510)\end{array}$ & 310 & 1,388 & 4.5 & 277.6 & 19 \\
\hline 7 & $\begin{array}{l}\text { The International Archives of the } \\
\text { Photogrammetry, Remote Sensing } \\
\text { and Spatial Information }\end{array}$ & $\begin{array}{l}1682- \\
1750\end{array}$ & 2015 & Non-APC & 1,865 & 2,910 & 1.6 & 582 & 18 \\
\hline 8 & $\begin{array}{l}\text { Engineering Applications of } \\
\text { Computational Fluid Mechanics }\end{array}$ & $\begin{array}{l}1994- \\
2060\end{array}$ & 2015 & $\$ 1,500$ & 259 & 1,272 & 4.9 & 254.4 & 17 \\
\hline 9 & $\begin{array}{l}\text { Journal of Environmental Health } \\
\text { and Engineering }\end{array}$ & $\begin{array}{l}1735- \\
1979\end{array}$ & 2006 & $\begin{array}{l}€ 600 \\
(\$ 666)\end{array}$ & 80 & 659 & 8.2 & 131.8 & 15 \\
\hline 10 & $\begin{array}{l}\text { International Journal of Rotating } \\
\text { Machinery }\end{array}$ & $\begin{array}{l}1023- \\
621 X\end{array}$ & 2002 & $\$ 600$ & 180 & 803 & 4.5 & 160.6 & 14 \\
\hline 11 & $\begin{array}{l}\text { Latin American Journal of Solids } \\
\text { and Structures }\end{array}$ & $\begin{array}{l}1679- \\
7817\end{array}$ & 2005 & Non-APC & 135 & 836 & 6.2 & 167.2 & 13 \\
\hline 12 & Bioresources and Bioprocessing & $\begin{array}{l}2197- \\
4365\end{array}$ & 2015 & Non-APC & 76 & 223 & 2.9 & 111.5 & 12 \\
\hline 13 & $\begin{array}{l}\text { Theoretical and Applied Mechanics } \\
\text { Letters }\end{array}$ & $\begin{array}{l}2095- \\
0349\end{array}$ & 2016 & $\$ 1,000$ & 415 & 883 & 2.1 & 176.6 & 12 \\
\hline 14 & Case Study in Thermal Engineering & $\begin{array}{l}2214- \\
157 X\end{array}$ & 2015 & $\$ 500$ & 102 & 566 & 5.6 & 188.7 & 12 \\
\hline
\end{tabular}




\begin{tabular}{|c|c|c|c|c|c|c|c|c|c|}
\hline 15 & $\begin{array}{l}\text { Engineering, Technology \& Applied } \\
\text { Science Research }\end{array}$ & $\begin{array}{l}2241- \\
4487\end{array}$ & & $\begin{array}{l}€ 140 \\
(\$ 155.4)\end{array}$ & 153 & 390 & 2.6 & 78.0 & 11 \\
\hline 16 & Advances in Civil Engineering & $\begin{array}{l}1687- \\
8086\end{array}$ & 2009 & $\$ 600$ & 460 & 874 & 2.0 & 174.8 & 11 \\
\hline 17 & Australian Educational Computing & $\begin{array}{l}0816- \\
9020\end{array}$ & 2015 & Non-APC & 80 & 243 & 3.0 & 48.6 & 10 \\
\hline 18 & $\begin{array}{l}\text { Paladyn: Journal of Behavioral } \\
\text { Robotics }\end{array}$ & $\begin{array}{l}2081- \\
4836\end{array}$ & 2015 & Non-APC & 68 & 363 & 5.3 & 72.6 & 10 \\
\hline 19 & $\begin{array}{l}\text { ISPRS Annals of the } \\
\text { Photogrammetry, Remote Sensing } \\
\text { and Spatial Information Sciences }\end{array}$ & $\begin{array}{l}2194- \\
9042\end{array}$ & 2015 & Non-APC & 356 & 524 & 1.5 & 131 & 10 \\
\hline 20 & Journal of Modern Transportation & $\begin{array}{l}2095- \\
087 X\end{array}$ & 2007 & $\begin{array}{l}€ 1,000 \\
(\$ 1,110)\end{array}$ & 174 & 472 & 2.7 & 94.4 & 10 \\
\hline 21 & $\begin{array}{l}\text { Journal of Control Science and } \\
\text { Engineering }\end{array}$ & $\begin{array}{l}1687- \\
5249\end{array}$ & 2015 & $\$ 600$ & 243 & 517 & 2.1 & 103.4 & 10 \\
\hline 22 & Journal of Engineering & $\begin{array}{l}2314- \\
4904\end{array}$ & 2013 & $\$ 600$ & 182 & 515 & 2.8 & 128.8 & 10 \\
\hline 23 & $\begin{array}{l}\text { Drinking Water Engineering and } \\
\text { Science (DWES) }\end{array}$ & $\begin{array}{l}1996- \\
9457\end{array}$ & 2009 & Non-APC & 54 & 154 & 2.9 & 30.8 & 9 \\
\hline 24 & Advances in OptoElectronics & $\begin{array}{l}1687- \\
563 X\end{array}$ & 2007 & $\$ 600$ & 103 & 362 & 3.5 & 72.4 & 9 \\
\hline 25 & $\begin{array}{l}\text { International Journal of Science and } \\
\text { Engineering }\end{array}$ & $\begin{array}{l}2086- \\
5023\end{array}$ & 2012 & Non-APC & 656 & 616 & 0.9 & 123.2 & 8 \\
\hline 26 & $\begin{array}{l}\text { Journal of Engineering Research } \\
\text { and Technology }\end{array}$ & $\begin{array}{l}2312- \\
2307\end{array}$ & 2014 & Non-APC & 21 & 545 & 26.0 & 109 & 8 \\
\hline 27 & $\begin{array}{l}\text { Case Studies in Engineering Failure } \\
\text { Analysis }\end{array}$ & $\begin{array}{l}2213- \\
2902\end{array}$ & 2015 & $\$ 500$ & 96 & 250 & 2.6 & 83.3 & 8 \\
\hline 28 & Journal of Industrial Engineering & $\begin{array}{l}2314- \\
4882\end{array}$ & 2013 & $\$ 600$ & 54 & 177 & 3.3 & 35.4 & 8 \\
\hline 29 & Nano Convergence & $\begin{array}{l}2196- \\
5404\end{array}$ & 2015 & Non-APC & 52 & 163 & 3.1 & 54.3 & 7 \\
\hline 30 & Advances in Radio Science ARS & $\begin{array}{l}1684- \\
9965\end{array}$ & 2004 & $\begin{array}{l}€ 150 \\
(\$ 166.5)\end{array}$ & 235 & 334 & 1.4 & 66.8 & 7 \\
\hline 31 & $\begin{array}{l}\text { Mehran University Research Journal } \\
\text { of Engineering and Technology }\end{array}$ & $\begin{array}{l}0254- \\
7821\end{array}$ & 2016 & $\begin{array}{l}\text { 3,000PKR } \\
(\$ 28.5)\end{array}$ & 378 & 295 & 0.8 & 59 & 7 \\
\hline
\end{tabular}




\begin{tabular}{|c|c|c|c|c|c|c|c|c|c|}
\hline 32 & Chinese Journal of Engineering & $\begin{array}{l}2314- \\
8063\end{array}$ & 2013 & $\$ 600$ & 897 & 626 & 0.7 & 125.2 & 7 \\
\hline 33 & $\begin{array}{l}\text { Atmospheric Measurement } \\
\text { Techniques Discussion }\end{array}$ & $\begin{array}{l}1867- \\
8610\end{array}$ & 2009 & $\begin{array}{l}€ 1,000 \\
(\$ 1,110)\end{array}$ & 308 & 337 & 1.1 & 67.4 & 7 \\
\hline 34 & $\begin{array}{l}\text { Turkish Journal of Computer and } \\
\text { Mathematical Education }\end{array}$ & $\begin{array}{l}1309- \\
4653\end{array}$ & 2015 & Non-APC & 127 & 192 & 1.5 & 38.4 & 6 \\
\hline 35 & Tecnura & $\begin{array}{l}0123- \\
921 X\end{array}$ & 2012 & Non-APC & 606 & 252 & 0.4 & 50.4 & 6 \\
\hline 36 & Jurnal Teknik ITS & $\begin{array}{l}2301 \\
9271\end{array}$ & 2015 & Non-APC & 714 & 355 & 0.5 & 88.8 & 6 \\
\hline 37 & $\begin{array}{l}\text { Metrology and Measurement } \\
\text { Systems }\end{array}$ & $\begin{array}{l}2300- \\
1941\end{array}$ & 2015 & Non-APC & 81 & 160 & 1.0 & 32 & 6 \\
\hline 38 & Revista Producao Online & $\begin{array}{l}1676- \\
1901\end{array}$ & 2006 & Non-APC & 262 & 269 & 1.0 & 53.8 & 6 \\
\hline 39 & Sensing and Bio-Sensing Research & $\begin{array}{l}2214- \\
1804\end{array}$ & 2016 & $\$ 750$ & 87 & 160 & 1.8 & 80 & 6 \\
\hline 40 & The Journal of Engineering & $\begin{array}{l}2051- \\
3305\end{array}$ & 2013 & $\$ 1,150$ & 183 & 116 & 0.6 & 38.7 & 6 \\
\hline 41 & Ciencia y Tecnologia & $\begin{array}{l}1390- \\
4051\end{array}$ & 2016 & Non-APC & 58 & 82 & 1.4 & 16.4 & 5 \\
\hline 42 & Journal of Daylighting & $\begin{array}{l}2383- \\
8701\end{array}$ & 2015 & Non-APC & 13 & 19 & 1.5 & 9.5 & 5 \\
\hline 43 & Telematika & $\begin{array}{l}1829- \\
667 X\end{array}$ & 2016 & Non-APC & 442 & 113 & 0.3 & 22.6 & 5 \\
\hline 44 & $\begin{array}{l}\text { Texto Livre: Linguagem e } \\
\text { Tecnologia }\end{array}$ & $\begin{array}{l}1983- \\
3652\end{array}$ & 2015 & Non-APC & 133 & 71 & 0.5 & 14.2 & 5 \\
\hline 45 & $\begin{array}{l}\text { Journal of Hebei University of } \\
\text { Science and Technology }\end{array}$ & $\begin{array}{l}1008- \\
1542\end{array}$ & 2015 & Non-APC & 355 & 344 & 1.0 & 68.8 & 5 \\
\hline 46 & $\begin{array}{l}\text { Revista Venezolana de Ciencia y } \\
\text { Tecnologia de Alimentos (RVCTA) }\end{array}$ & $\begin{array}{l}2218- \\
4384\end{array}$ & 2015 & Non-APC & 106 & 90 & 0.9 & 18 & 5 \\
\hline 47 & Technologies (Basel) & $\begin{array}{l}2227- \\
7080\end{array}$ & 2014 & Non-APC & 35 & 99 & 2.8 & 33 & 5 \\
\hline 48 & $\begin{array}{l}\text { Advances in Science and } \\
\text { Technology Research Journal }\end{array}$ & $\begin{array}{l}2080- \\
4075\end{array}$ & 2015 & Non-APC & 216 & 156 & 0.7 & 39 & 5 \\
\hline
\end{tabular}




\begin{tabular}{|c|c|c|c|c|c|c|c|c|c|}
\hline 49 & $\begin{array}{l}\text { Vestnik Volgogradskogo } \\
\text { Gosudarstvenngo Universiteta. Seria } \\
\text { 10. Innovacionnaa Deatel'nost' }\end{array}$ & $\begin{array}{l}2305- \\
7815\end{array}$ & 2015 & Non-APC & 225 & 93 & 0.4 & 18.6 & 5 \\
\hline 50 & Ingenieria y Ciencia & $\begin{array}{l}1794- \\
9165\end{array}$ & 2012 & Non-APC & 240 & 106 & 0.4 & 21.2 & 5 \\
\hline 51 & $\begin{array}{l}\text { Journal of Technology and Science } \\
\text { Education }\end{array}$ & $\begin{array}{l}2013- \\
6374\end{array}$ & 2011 & Non-APC & 104 & 106 & 1.0 & 21.2 & 5 \\
\hline 52 & Bioengineering (Basel) & $\begin{array}{l}2306- \\
5354\end{array}$ & 2014 & Non-APC & 33 & 61 & 1.9 & 20.3 & 5 \\
\hline 53 & $\begin{array}{l}\text { Journal of Quality and Reliability } \\
\text { Engineering }\end{array}$ & $\begin{array}{l}2314- \\
8055\end{array}$ & 2013 & $\$ 600$ & 35 & 80 & 2.3 & 26.7 & 5 \\
\hline 54 & $\begin{array}{l}\text { Journal of Engineering and } \\
\text { Technological Sciences }\end{array}$ & $\begin{array}{l}2337- \\
5779\end{array}$ & 2015 & $\$ 100$ & 136 & 126 & 0.9 & 25.2 & 5 \\
\hline 55 & Journal of Solid State Lighting & $\begin{array}{l}2196- \\
1107\end{array}$ & 2015 & $\begin{array}{l}€ 1,000 \\
(\$ 1,110)\end{array}$ & 36 & 115 & 3.2 & 23 & 5 \\
\hline 56 & Journal of Agricultural Machinery & $\begin{array}{l}2228- \\
6829\end{array}$ & 2016 & $\begin{array}{l}1,000,000 \\
\text { IRR }(\$ 32)\end{array}$ & 75 & 89 & 1.2 & 17.8 & 5 \\
\hline 57 & Bibechana & $\begin{array}{l}2091- \\
0762\end{array}$ & 2016 & Non-APC & 135 & 65 & 0.5 & 13 & 4 \\
\hline 58 & $\begin{array}{l}\text { Journal of Mechatronics, Electrical } \\
\text { Power, and Vehicular Technology }\end{array}$ & $\begin{array}{l}2087- \\
3379\end{array}$ & 2013 & Non-APC & 138 & 86 & 0.6 & 17.2 & 4 \\
\hline 59 & $\begin{array}{l}\text { Journal of Applied Biotechnology } \\
\text { Reports }\end{array}$ & $\begin{array}{l}2322- \\
1186\end{array}$ & 2015 & Non-APC & 52 & 12 & 0.2 & 6 & 4 \\
\hline 60 & $\begin{array}{l}\text { Quantum Measurements and } \\
\text { Quantum Metrology }\end{array}$ & $\begin{array}{l}2299- \\
114 X\end{array}$ & 2015 & Non-APC & 10 & 37 & 3.7 & 12.3 & 4 \\
\hline 61 & $\begin{array}{l}\text { Evropejskij Zurnal Tehniki I } \\
\text { Dizajna }\end{array}$ & $\begin{array}{l}2308- \\
6505\end{array}$ & 2016 & Non-APC & 39 & 123 & 3.2 & 41 & 4 \\
\hline 62 & ComTech & $\begin{array}{l}2087- \\
1244\end{array}$ & 2016 & Non-APC & 442 & 41 & 0.1 & 8.2 & 4 \\
\hline 63 & Cogent Engineering & $\begin{array}{l}2331- \\
1916\end{array}$ & 2014 & $\$ 1,250$ & 105 & 86 & 0.8 & 43 & 4 \\
\hline 64 & Frontiers in Built Environment & $\begin{array}{l}2297- \\
3362\end{array}$ & 2015 & $\$ 1,900$ & 23 & 53 & 2.3 & 53 & 4 \\
\hline 65 & $\begin{array}{l}\text { International Journal of } \\
\text { Manufacturing Engineering }\end{array}$ & $\begin{array}{l}2356- \\
7023\end{array}$ & 2014 & $\$ 600$ & 33 & 46 & 1.4 & 15.3 & 4 \\
\hline
\end{tabular}




\begin{tabular}{|c|c|c|c|c|c|c|c|c|c|}
\hline 66 & Journal Energi Dan Manufaktur & $\begin{array}{l}2302- \\
5255\end{array}$ & 2016 & Non-APC & 101 & 27 & 0.3 & 5.4 & 3 \\
\hline 67 & Scietia cum Industria & $\begin{array}{l}2318- \\
5279\end{array}$ & 2015 & Non-APC & 37 & 9 & 0.2 & 3 & 3 \\
\hline 68 & $\begin{array}{l}\text { Tecnologia em Metalurgia Materiais } \\
\text { e Mineracao (TMM) }\end{array}$ & $\begin{array}{l}2176- \\
1515\end{array}$ & 2016 & Non-APC & 192 & 38 & 0.2 & 7.6 & 3 \\
\hline 69 & Tecno Logicas & $\begin{array}{l}0123- \\
7799\end{array}$ & 2013 & Non-APC & 211 & 82 & 0.4 & 16.4 & 3 \\
\hline 70 & $\begin{array}{l}\text { Al-Qadisiyah Journal for } \\
\text { Engineering Science }\end{array}$ & $\begin{array}{l}1998- \\
4456\end{array}$ & 2016 & $\$ 50$ & 19 & 299 & 15.7 & 59.8 & 3 \\
\hline 71 & $\begin{array}{l}\text { Civil and Environmental } \\
\text { Engineering }\end{array}$ & $\begin{array}{l}1336- \\
5835\end{array}$ & 2016 & $\begin{array}{l}€ 60 \\
(\$ 66.6)\end{array}$ & 69 & 28 & 0.4 & 5.6 & 3 \\
\hline 72 & Microsystems \& Nanoengineering & $\begin{array}{l}2055- \\
7434\end{array}$ & 2016 & $\left|\begin{array}{l}£ 2,650 \\
(\$ 3,471.5)\end{array}\right|$ & 20 & 34 & 1.7 & 34 & 3 \\
\hline 73 & $\begin{array}{l}\text { Journal of Rehabilitation in Civil } \\
\text { Engineering }\end{array}$ & $\begin{array}{l}2345- \\
4423\end{array}$ & 2016 & Non-APC & 34 & 16 & 0.5 & 5.3 & 2 \\
\hline 74 & $\begin{array}{l}\text { Drinking Water Engineering and } \\
\text { Science Discussions }\end{array}$ & $\begin{array}{l}1996- \\
9473\end{array}$ & 2009 & Non-APC & 13 & 12 & 0.9 & 2.4 & 2 \\
\hline 75 & $\begin{array}{l}\text { International Journal of Electronics, } \\
\text { Mechanical and Mechatronics } \\
\text { Engineering }\end{array}$ & $\begin{array}{l}2146- \\
0604\end{array}$ & 2015 & Non-APC & 6 & 8 & 1.3 & 1.6 & 2 \\
\hline 76 & Jurnal Tribologi & $\begin{array}{l}2289- \\
7232\end{array}$ & 2016 & Non-APC & 12 & 15 & 1.25 & 7.5 & 2 \\
\hline 77 & Cadernos de Prospeccao & $\begin{array}{l}1983- \\
1358\end{array}$ & 2010 & Non-APC & 257 & 33 & 0.1 & 16.5 & 2 \\
\hline 78 & $\begin{array}{l}\text { Multidisciplinary Journal for } \\
\text { Education, Social and } \\
\text { Technological Sciences }\end{array}$ & $\begin{array}{l}2341- \\
2593\end{array}$ & 2015 & Non-APC & 42 & 10 & 0.2 & 5 & 2 \\
\hline 79 & $\begin{array}{l}\text { REEC: Revista Electronica de } \\
\text { Engenharia Civil }\end{array}$ & $\begin{array}{l}2179- \\
0612\end{array}$ & 2016 & Non-APC & 76 & 24 & 0.3 & 4.8 & 2 \\
\hline 80 & Epistemus & $\begin{array}{l}2007- \\
4530\end{array}$ & 2016 & Non-APC & 6 & 14 & 2.3 & 2.8 & 2 \\
\hline 81 & Bionatura & $\begin{array}{l}1390- \\
9347\end{array}$ & 2016 & Non-APC & 29 & 19 & 0.7 & 3.8 & 2 \\
\hline 82 & $\begin{array}{l}\text { Nauka I Tehnika (Science } \\
\text { Technique) }\end{array}$ & $\begin{array}{l}2227- \\
1031\end{array}$ & 2016 & Non-APC & 9 & 17 & 1.9 & 3.4 & 2 \\
\hline
\end{tabular}




\begin{tabular}{|c|c|c|c|c|c|c|c|c|c|}
\hline 83 & $\begin{array}{l}\text { Revista Chilena de Derecho y } \\
\text { Tecnologia }\end{array}$ & $\begin{array}{l}0719- \\
2584\end{array}$ & 2015 & Non-APC & 41 & 16 & 0.4 & 4 & 2 \\
\hline 84 & Case Studies in Fire Safety & $\begin{array}{l}2214- \\
398 X\end{array}$ & 2015 & $\$ 500$ & 22 & 24 & 1.9 & 10.3 & 2 \\
\hline 85 & $\begin{array}{l}\text { Journal of Applied Engineering } \\
\text { Sciences }\end{array}$ & $\begin{array}{l}2247- \\
3769\end{array}$ & 2015 & $\begin{array}{l}€ 40 \\
(\$ 44.4)\end{array}$ & 97 & 20 & 0.2 & 5 & 2 \\
\hline 86 & Jurnal Spektran & $\begin{array}{l}2302- \\
2590\end{array}$ & 2015 & $\$ 50$ & 54 & 26 & 0.5 & 5.2 & 2 \\
\hline 87 & $\begin{array}{l}\text { International Journal of Engineering } \\
\text { and Technology Innovation }\end{array}$ & $\begin{array}{l}2223- \\
5329\end{array}$ & 2015 & Non-APC & 7 & 1 & 0.1 & 0.2 & 1 \\
\hline 88 & $\begin{array}{l}\text { EAI Endorsed Transactions on } \\
\text { Security and Safety }\end{array}$ & $\begin{array}{l}2032- \\
9393\end{array}$ & 2016 & Non-APC & 2 & 6 & 3.0 & 6 & 1 \\
\hline 89 & $\begin{array}{l}\text { International Journal of Advances in } \\
\text { Intelligent Informatics }\end{array}$ & $\begin{array}{l}2442- \\
6571\end{array}$ & 2015 & Non-APC & 2 & 6 & 3 & 6 & 1 \\
\hline 90 & IF-Sophia & $\begin{array}{l}2358- \\
7482\end{array}$ & 2016 & Non-APC & 4 & 1 & 0.3 & 1 & 1 \\
\hline 91 & Journal of Dental Biomaterial & $\begin{array}{l}2383- \\
3971\end{array}$ & 2015 & Non-APC & 5 & 2 & 0.4 & 0.5 & 1 \\
\hline 92 & $\begin{array}{l}\text { Engaging Science, Technology, and } \\
\text { Society (ESTS) }\end{array}$ & $\begin{array}{l}2413- \\
8053\end{array}$ & 2016 & Non-APC & 12 & 8 & 0.6 & 2.7 & 1 \\
\hline 93 & Inge@UAN & $\begin{array}{l}2145- \\
0935\end{array}$ & 2015 & Non-APC & 77 & 5 & 0.1 & 1 & 1 \\
\hline 94 & $\begin{array}{l}\text { Jurnal Teknosain: Jurnal Ilmiah } \\
\text { Sains dan Teknologi }\end{array}$ & $\begin{array}{l}2089- \\
6131\end{array}$ & 2016 & Non-APC & 14 & 2 & 0.1 & 0.4 & 1 \\
\hline 95 & $\begin{array}{l}\text { EAI Endorsed Transactions on } \\
\text { Collaborative Computing }\end{array}$ & $\begin{array}{l}2312- \\
8623\end{array}$ & 2016 & Non-APC & 3 & 1 & 0.3 & 0.5 & 1 \\
\hline 96 & Journal Keteknikan Pertanian & $\begin{array}{l}2407- \\
0475\end{array}$ & 2016 & $\begin{array}{l}100,000 \\
\text { IDR } \\
(\$ 7.6)\end{array}$ & 3 & 12 & 4 & 12 & 1 \\
\hline 97 & $\begin{array}{l}\text { Mechanics of Advanced Materials } \\
\text { and Modern Processes }\end{array}$ & $\begin{array}{l}2198- \\
7874\end{array}$ & 2015 & $\begin{array}{l}€ 300 \\
(\$ 333)\end{array}$ & 7 & 3 & 0.9 & 0.4 & 1 \\
\hline 98 & $\begin{array}{l}\text { RCT Revista de Ciencia e } \\
\text { Tecnologia }\end{array}$ & $\begin{array}{l}2447- \\
7028\end{array}$ & 2016 & Non-APC & 7 & 0 & 0 & 0 & 0 \\
\hline 99 & Acta Tecnologia & $\begin{array}{l}2453- \\
675 X\end{array}$ & 2016 & Non-APC & 3 & 0 & 0 & 0 & 0 \\
\hline
\end{tabular}




\begin{tabular}{|l|l|l|l|l|l|l|l|l|l|}
\hline 100 & $\begin{array}{l}\text { EAI Endorsed Transactions on } \\
\text { Creative Technology }\end{array}$ & $\begin{array}{l}2409- \\
9708\end{array}$ & 2015 & Non-APC & 4 & 0 & 0 & 0 & 0 \\
\hline 101 & $\begin{array}{l}\text { Mexican Journal of Materials } \\
\text { Science and Engineering }\end{array}$ & $\begin{array}{l}2395- \\
9630\end{array}$ & 2016 & Non-APC & 15 & 0 & 0 & 0 & 0 \\
\hline 102 & $\begin{array}{l}\text { International Journal of Research } \\
\text { and Innovations in Science and } \\
\text { Technology }\end{array}$ & $\begin{array}{l}2394- \\
3858\end{array}$ & 2015 & Non-APC & 10 & 0 & 0 & 0 & 0 \\
\hline 103 & $\begin{array}{l}\text { EAI Endorsed Transactions on e- } \\
\text { Learning }\end{array}$ & $\begin{array}{l}2032- \\
9253\end{array}$ & 2015 & Non-APC & 2 & 0 & 0 & 0 & 0 \\
\hline$* 104$ & $\begin{array}{l}\text { EAI Endorsed Transactions on } \\
\text { Wireless Spectrum }\end{array}$ & $\begin{array}{l}2312- \\
6620\end{array}$ & 2015 & Non-APC & & & & & $</$ td \\
\hline$*$ Not Indexed
\end{tabular}




\section{Appendix 2}

APC Engineering and Technology Journals and Their Publishers

\begin{tabular}{|l|l|l|}
\hline & \multicolumn{1}{|c|}{ Journals } & \multicolumn{1}{|c|}{ Publisher } \\
\hline 1 & Mathematical Problems in Engineering & Hindawi \\
\hline 2 & Materials & MDPI \\
\hline 3 & Applied Sciences & MDPI \\
\hline 4 & $\begin{array}{l}\text { Engineering Applications of Computational Fluid } \\
\text { Mechanics }\end{array}$ & Taylor \& Francis \\
\hline 5 & Journal of Environmental Health and Engineering & BioMed Central \\
\hline 6 & International Journal of Rotating Machinery & Hindawi \\
\hline 7 & Theoretical and Applied Mechanics Letters & Elsevier \\
\hline 8 & Case Study in Thermal Engineering & Elsevier \\
\hline 9 & Engineering, Technology \& Applied Science Research & ETASR \\
\hline 10 & Advances in Civil Engineering & Hindawi \\
\hline 11 & Journal of Modern Transportation & Springer \\
\hline 12 & Journal of Control Science and Engineering & Hindawi \\
\hline 13 & Journal of Engineering & Hindawi \\
\hline 14 & Advances in OptoElectronics & Hindawi \\
\hline 15 & Case Studies in Engineering Failure Analysis & Elsevier \\
\hline 16 & Journal of Industrial Engineering & Hindawi \\
\hline 17 & Advances in Radio Science ARS & URSI \\
\hline 18 & $\begin{array}{l}\text { Mehran University Research Journal of Engineering and } \\
\text { Technology }\end{array}$ & Mehran University \\
\hline 19 & Chinese Journal of Engineering & Hindawi \\
\hline 20 & Atmospheric Measurement Techniques Discussion & European Geoscience Union \\
\hline 21 & Sensing and Bio-Sensing Research & Elsevier \\
\hline 22 & The Journal of Engineering & Institute of Engineering Tech \\
\hline 23 & Journal of Quality and Reliability Engineering & Hindawi \\
\hline 24 & Journal of Engineering and Technological Sciences & Institut Teknologi Bandung \\
\hline 25 & Journal of Solid State Lighting & Springer \\
\hline
\end{tabular}




\begin{tabular}{|l|l|l|}
\hline 26 & Journal of Agricultural Machinery & $\begin{array}{l}\text { Ferdowsi University of } \\
\text { Mashhad }\end{array}$ \\
\hline 27 & Cogent Engineering & Taylor \& Francis \\
\hline 28 & Frontiers in Built Environment & $\begin{array}{l}\text { Swiss Federal Institute of } \\
\text { Technology }\end{array}$ \\
\hline 29 & International Journal of Manufacturing Engineering & Hindawi \\
\hline 30 & Al-Qadisiyah Journal for Engineering Science & Al-Qadisiyah University \\
\hline 31 & Civil and Environmental Engineering & De Gruyter \\
\hline 32 & Microsystems \& Nanoengineering & IECAS \\
\hline 33 & Case Studies in Fire Safety & Elsevier \\
\hline 34 & Journal of Applied Engineering Sciences & University of Oradea \\
\hline 35 & Jurnal Spektran & Universitas Udayana \\
\hline 36 & Journal Keteknikan Pertanian & Institut Pertanian Bogor \\
\hline 37 & Mechanics of Advanced Materials and Modern Processes & Springer \\
\hline
\end{tabular}
cc) (†)

This work is licensed under a Creative Commons Attribution 4.0 International License. 